\title{
Advanced Developments in Aquaponics
}

\author{
Yurina N.A.* \\ Laboratory of Feeding and physiology of farm animals \\ Krasnodar Research Centre for Animal Husbandry and \\ Veterinary Medicine \\ Krasnodar, Russia \\ Department of Biotechnology, Biochemistry and Biophysics, \\ Kuban State Agrarian University named after I.T. Trubilin, \\ Krasnodar, Russia \\ naden8277@mail.ru \\ Maksim E.A. \\ Laboratory of Feeding and physiology of farm animals \\ Krasnodar Research Centre for Animal Husbandry and \\ Veterinary Medicine \\ Krasnodar, Russia \\ 4806144@mail.ru
}

\author{
Yurin D.A. \\ Department of Livestock technology \\ Krasnodar Research Centre for Animal Husbandry and \\ Veterinary Medicine \\ Krasnodar, Russia \\ 4806144@mail.ru
}

\author{
Osepchuk D.V. \\ Department of Livestock technology \\ Krasnodar Research Centre for Animal Husbandry and \\ Veterinary Medicine \\ Krasnodar, Russia \\ osepchuk81@mail.ru
}

\author{
Ustjuzhaninova T.A. \\ Department of Technology, Machines and Equipment for Food Production, \\ Maykop State Technological University \\ Maykop, Russia \\ 4806144@mail.ru
}

\begin{abstract}
The article presents the results of experiments to improve the method of aquaponics grown on a pontoon plant. The aquaponic installation can be optimized as follows: when using the protective net, it is possible to minimize the eating of plants by birds and their death from insolation, it is necessary to exclude white amur from the ichthyofauna. The data obtained indicate that in order to obtain hydroponic fodder it is advisable to use water from a regulated runoff of the Albashi River (experimental reservoir), where an aquaponic plant was used in a fish farm, saturated with nutrients for aquaponics. Plant losses are minimized due to installation of protective net as an obstacle from eating by birds and increased solar insulation, also the correction of selection of fish exploration objects.
\end{abstract}

Keywords - aquaponics, aquaponic plant, fish exploration, parsley, solar, ichthyofauna.

\section{INTRODUCTION}

There is a question of the combination of industries arises in the context of the intensification of agriculture. As a result aquaponics is becoming increasingly relevant, because is possible to obtain safe fish and crop production products [1].

Joint cultivation of fish and plants is very perspective direction of food production, which has got a great interest for peasant-farm farms and for larger enterprises.

The increase of economic efficiency in this case is due to the fact that fish and cultivated plants have got similar needs for energy and heat costs [2-4].
In industrial conditions with the use of intensive technologies [5-7] (compacted planting, feeding) in pools with closed or revolving water supply there is accumulation of fish life products. Their oxidation and the oxidation of feed residues, can lead to an increase in the water content of compounds such as nitrates and phosphates.

In order to avoid the negative consequences of exposure to elevated concentrations of these substances, various settling tanks and filters are used such as control landing densities, feeding standards and so on. $[8,9]$.

However, products of nitrogenous exchange (ammonium, nitrites and nitrates) can be used as nutrients in the cultivation of various agricultural plants. Such as tomatoes, cucumbers, basil, lettuce and other crops [10].

Today, aquaponics is a perspective direction of growing plants without soil in terms of combining the technology of intensive sturgeon breeding and crop production, as a result it turns out a complex of environmentally safe fish and crop production products.

Especially it is relevant with the increase of sturgeon farms in connection with "The Development Strategy of Aquaculture in the Russian Federation until 2020."

In the conditions of deficiency of high-quality food and the insistence of the population for their safety, there is a question of connecting fish farming and crop production together. Aquaponic can save this problem. 
The quality of the products produced by use technology of aquaponics is estimated by the chemical composition of aquaponic plants. Their lack of toxic substances, the amount of oxygen released to wastewater and the number of consumed biogens $[11,12]$.

However, sturgeon breeding is not limited by basin content and it is often combined with pond fish farming [13, 14].

Thus, we have made attempts to connect pond fish farming (aquaculture) with the cultivation of plants without soil (hydroponics) on the surface of the water basin.

\section{RESEARCH MATERIAL AND TECHNIQUE}

The purpose of the researches was to modernize the pontoon aquaponic plant by carrying out acute experiments on the surface of the water basin during fish breeding.

The following objectives have been identified and achieved:

1) determine the degree of eating plants by birds.

2) identify the possibility of co-cultivation of plants and fish together;

3) determine the effect of solar insolation on the plant growth.

Subject of research: parsley seeds.

Object of research: pontoon installation and aquaponics as a method of growing plants without soil

Research hypothesis is represented by the assumption that the cultivation of parsley seeds plant is low-cost and rapid in a pontoon aquaponics.

There are two channel ponds in the fish farming farm of "Albashi" LLC located in Leningrad district of Krasnodar Territory with a total area of 35 hectares.

The average depth of ponds is $1.3-1.8 \mathrm{~m}$, the maximum depth is up to $3 \mathrm{~m}$.

The ponds are divided by earthen dams. There are facilities for the passage of household and flood expenses along the Albashi River on each dam.

The length of the Albashi River is $64 \mathrm{~km}$ and its basin is $895 \mathrm{~km} 2$. It has 43 dams.

"Albashi" LLC is an enterprise engaged in breeding and growing pond fish and sturgeon in pools and gardens, cancers, growing aquaponics greens.

Average daily temperature conditions (as a result of daily thermometer measurements) in 2019 in the conditions of "Albashi" LLC were following: January: 0, $3{ }^{\circ} \mathrm{C}$; February: $0.4{ }^{\circ} \mathrm{C}$; March: $4.9{ }^{\circ} \mathrm{C}$; April: $10.2{ }^{\circ} \mathrm{C}$; May: $17.4{ }^{\circ} \mathrm{C}$; June: $21.2{ }^{\circ} \mathrm{C}$; July: $23.1{ }^{\circ} \mathrm{C}$; August: $23.2{ }^{\circ} \mathrm{C}$; September: $17.4{ }^{\circ} \mathrm{C}$; October: $12.1{ }^{\circ} \mathrm{C}$; November: $5.2{ }^{\circ} \mathrm{C}$; December: $0.5{ }^{\circ} \mathrm{C}$.

According to the classification of saprobity zones, this water reservoir corresponds to the b-mesosaprobic zone (purity class II or "water moderately clean, moderately (weakly) contaminated).
In this zone oxygen content fluctuates depending on the time of day: during the day excess oxygen, at night - vice versa.

In the b-mesosaprobe zone oxygen conditions are aerobic. There are ammonium salts, nitrates and nitrites from nitrous compounds, little hydrogen sulphide, water body does not rot, $1 \mathrm{ml}$ of water contains tens of thousands of bacteria, variety of species is significant, change of communities is rather slow and the need of organisms for oxygen is large.

Water reservoirs of this zone are favorable for breeding fish and cancers. Also, the composition of water is favorable for the development of plants.

Ichtioplankton of ponds of "Albashi" LLC is represented by the following kinds of fish. They are: white amur, white fat, sazan or common carp.

In order to restore the natural ichthyofauna of the water basin and creation of press of predators, sudak and a pike are planted in the water basin.

To feed predatory kinds of fish, weed fish of water bodies are used. In order to feed predatory kinds of fish and to grow them faster each year, silver caraway is introduced into ponds.

White amour (lat. Ctenopharyngodon idella) is a kind of ray fish from families.

Fish cultivation in the chest water reservoir is carried out by an intensive method, so with the use of mineral fertilizers and feeding of fish (carpa) with mixed fodders, necessarily containing the methods we have developed for feeding fish with probiotics and phytobiotics (coniferous phytobiotics (Russian Patent No. 2676727 of 10.01.2019). It additionally contributes to the increase of nutrients and biologically active substances in water, which are used favourably by plants.

The composition of compound feed for carp was developed using the program for calculation of diets to agricultural animals (certificate of state registration of the program for computer № 2019667345 from 23.12.2019, authors Yurin D.A., Yurina N.A.), tested and used in the farm the following. They are:

- Fish flour (10.0\%);

- Fodder yeast (14.0\%);

- Yeast-hydrolysed (20.0\%);

- Sunflower kernels (26.9\%);

- Wheat (19.0\%);

- Molasses (3.0\%);

- Softwood phytodilator $(3.0 \%)$

- Methionine $(0.5 \%)$;

- PF-2V premix (1.0\%);

- Inorganic phosphate $(1.0 \%)$;

- Chalk $(1.0 \%)$;

- Probiotic "Bacell-M" - (0.6\%). 
The feed contains not less than $26.0 \%$ protein, $3.0 \%$ fat, not more than $9.0 \%$ fiber. For sturgeon developed and used fodders with protein content of not less than $40.0 \%, 3.5 \%$ fat and fiber of not more than $8.0 \%$.

In fish farming probiotics and phytobiotics significantly optimize the hydrochemical composition of water, have got positively effect on the prevention of bacterial disease outbreaks and lead to an increase in fish productivity and safety of fish by 10-16\%. Therefore, the complex application of the technology of growing plants without soil, along with the use of bio preparations and phytobiotics in the feeding system of all types of fish, allows preventing mucous and bacterial diseases of plants, so as part of the introduced bio preparation up to $15-20 \%$ comes into water from feed and fishing life products.

Subject to this amendment, dosages of feed additives for fish have been developed.

In addition, it is desirable to introduce probiotic bio preparations into the water. In this direction developed the Patent of the Russian Federation for the invention № 2574131 "Method of growing young fish," 2016.

The reservoir is stocked up annually with high-quality planting material for fish (year-old or year-old) weighing 50-80 g, which is imported from RSP Angelinsky LLC (Tribal Plant, Staronizhesteblievskaya station of the Krasnoarmeysky district of the Krasnodar Territory.

When growing fish intensively, feeding begins after a fish transplant, at a water temperature of $+8 \ldots+10^{\circ} \mathrm{C}$. In the first 10 days after transplantation, fish are fed once a day, with a rise in water temperature above $18{ }^{\circ} \mathrm{C}$, two-time feeding begins.

Fodder places are located along the coast at a depth of 0.5 to $1.5 \mathrm{~m}$ in areas with solid soil, mark with sticks or buoys. Its sizes are from 5 to $10 \mathrm{~m}^{2}$.

By adding calcium, the mineralization of organic sludge, compaction of the soil and the creation of an alkaline environment at the feeding sites are achieved.

When carp is grown in polyculture, the daily feeding rate is increased in proportion to the number of herbivorous fish.

Channel ponds are calcified in autumn immediately after harvesting and in the spring before stocking at the rate of $200-300 \mathrm{~kg} / \mathrm{ha}$.

This contributes to the strengthening of oxidation processes, the destruction of the acid zones and the enrichment of water with nutrients. During the season, lime is classified systematically in accordance with the data of hydrochemical analysis, until July 1 after 10 days, from July 1 to September 1 - after 7 days. Lime is applied in the morning with clear sunny weather of $150-200 \mathrm{~kg} / \mathrm{ha}$.

In the summer months, shallow areas of the pond are overgrown with hard aquatic vegetation. It is necessary to periodically mow hard aquatic vegetation.

In order to achieve the planned fish productivity, mineral fertilizers are applied evenly on the surface of the reservoir.
The timing of fertilizer is determined by the degree of development of phytoplankton. Superphosphate is added if the total phosphorus content in the water after liming is below $0.40 \mathrm{mg} / \mathrm{l}$, the doses of nitrogen fertilizers are similar to the first option. Fertilization of deep-water areas of the pond is allowed after the destruction of inland zones.

The total consumption of fertilizers for the entire season is $100-300 \mathrm{~kg} / \mathrm{ha}$ of ammonium nitrate and superphosphate.

The catching of reservoirs is also envisaged annually when the fish reaches the standard commercial mass.

Based on the generalization of fish growing technology and intensification work (feeding, fertilizing), we can conclude that under these conditions it is quite possible to obtain fish productivity of up to $2200 \mathrm{~kg} / \mathrm{ha}$. It is especially important to fertilize the ponds, according to the above scheme, in order to maintain saprobity at the chosen optimal level. Feeding was carried out without the fact of overfeeding, which, in turn, favorably affects the hydrochemical regime.

Fresh water reservoirs of the reservoir type contain a large number of sapropelic sediments of various chemical compositions. In the case of insufficient suspension in water containing the necessary nutrients for cultivated plants, it is always possible to compensate for them by redistributing the layers of water from the bottom of the reservoir enriched with suspensions to the level of the developed plant for growing plants without soil.

The hydrogen indicator of the water of the reservoir $(\mathrm{pH})$, according to periodic measurements, using an Expert-pH $\mathrm{pH}$ meter $(3 \times 1)$, corresponded to $7.2 \pm 0.02$.

The hydrochemical regime of the reservoirs of Albashi LLC is fully consistent with the cultivation of hydroponic plants. In water, there is a sufficient amount of suspended solids $\left(8.2 \mathrm{mg} / \mathrm{dm}^{3}\right)$. In addition, it is planned to conduct an experiment on the redistribution of water layers in order to increase the volume of suspended solids (in 2020) to optimize plant growth. The complete absence pesticides characterize the resulting product as environmentally friendly.

\section{RESULTS OF RESEARCHES}

We have developed and tested a pontoon plant for the cultivation of aquapon plants. To test the experimental pontoon designs for the cultivation of aquapon plants, an experimental water body was used in "Albashi" LLC of the Leningrad district of Krasnodar Territory, with an area of 20 hundred.

During works on aquaponic technology on the pontoon installation, the following critical points were identified. They are:

- Eating plants by birds (100\%);

- Eating plants by vegetable fishes (white amur) (45\%);

- Increased solar insolation between July and August.

During production of a series of single-factor experiments, 180 cups with parsley seeds were planted in a pontoon plant. 
Experiments were carried out to refine optimal plant growth under aquaponics conditions. Seed germination was at $98.0-99.0 \%[15,16]$.

During the production of the first experience in May (02.05.2019) parsley seeds were planted with the appearance of seedlings. When the size of the sprouts reached $5 \mathrm{~cm}$, the aquaponic plant was eaten by birds in an amount of $100 \%$.

Young growth is attractive to birds and easily accessible in comparison to plants on coasts. Therefore, it is necessary to install protective nets against birds.

Therefore, we have developed an optimized aquaponic plant with a protective net against birds. That has protection efficiency of $95 \%$.

In the second experiment (25.05.2019) with the planting of parsley seeds, with a protective net from birds, the pond with the installation of aquaponics contained fishes: carp, sazan, carass, fat and white amur and black amur. White amur extensively ate plants at the edges of the plant in the amount of $45 \%$, White amur extensively ate plants at the edges of the plant in the amount of $45 \%$, therefore, when the amur was caught from the experimental pond, the remaining plants reached their growth without difficulty in 35 days.

In addition, as it turned out in the third experiment (planting of parsley seeds) in July (18.07.2019) with the use of repellent plants for birds, increased solar $t$ After the appearance of seedlings, in the presence of increased solar insulation, at this stage of plant formation their death was $47 \%$ with slowing growth of the remaining ones and loss of their commercial appearance.

Increased solar exposure was aggravated by the reflectivity of the water surface. Therefore, a grid protecting plants from birds is optimized, and a universal protective grid against eating plants by birds and for protecting against direct sunlight is used.

In the fourth experiment (02.08.2019), during parsley seeds planting with application of universal protective net, plant vegetation took 35 days and until its completion plant safety amounted to $90.0 \%$. One plant produced $29,0 \pm 0.3 \mathrm{~g}$ green mass $(\mathrm{n}=100)$.

Consequently, the developed aquaponic system optimally occurs cultivation of plants in the spring and autumn period, but taking into account the exclusion of white amur from the water basin and installations to scare birds used in fish farms.

In summer, it is necessary to use a universal protective net. Based on the researches, theoretical knowledge on methods of producing hydroponic plants has been expanded, new scientific data on the cultivation of plants without soil on the surface of internal fresh water reservoirs, opening of ways of application of new methods of obtaining additional products in the aquaculture industry and creation of an aquaponic plant.

Based on the results of the application of the aquaponic plant, it is possible to draw following conclusions:

- The design and operation of an aquaponic plant is costeffective;
- It is always possible to easily and quickly dismantle the aquaponic pontoon plant and move it to another place for further operation;

- Containers (cups) for plants are presented in a wide size series and are selected individually for each particular kind of plant being grown;

- Aquaponics products are always in demand in the market and are successfully sold both in wholesale and in retail.

Our technology differs significantly from existing analogues in that:

1. It is possible to combine several branches of agriculture: basin sturgeon, pond fish farming and growing hydroponic plants;

2. The system developed not only contributes to additional profits from farm fish farming, but also to the purification of water reservoirs and the prevention of their degradation;

3. Pontoons can be used throughout all the reservoirs of water;

4. Environmentally friendly feed for fish of all kinds is used, with the inclusion of functional feed ingredients (probiotic biopreparations and phytobiotics), which also have a beneficial effect on the hydrochemical characteristics of water.

The reliability of investments in the project is ensured by demand for the produced products, quality, availability of raw materials and raw materials, stable income generation.

The experience of germinating wheat grains was carried out in the conditions of fish farming of LLC Albashi in the Leningrad district of the Krasnodar Territory in the springsummer period of 2019.

To determine the optimal duration of cultivation, wheat germinated for 7 days.

From the seeds of the main culture, 3 samples of 100 pieces each were taken to determine germination and germination rate (GOST 12038-84).

The wheat grains of the first (control) sample were flooded with tap water, the second with water from a regulated runoff of the Albashi river (experimental reservoir), and the third with water from a well.

The data obtained were processed by the method of variation statistics (G.F. Lakin, 1990).

When germinating samples of 100 seeds in each germination percentage was 97,99 and $98 \%$, and the average germination rate was $98 \%$. For an average germination rate of $98 \%$, the tolerance is $\pm 3 \%$. Since the actual deviations of the results of the analysis of individual samples from the average value of germination do not exceed the permissible, the analysis should not be repeated.

From the obtained results it follows that the length of the sprouts on day 3 significantly increased in the second sample, 
flooded with water from the experimental reservoir - by $35.2 \%(\mathrm{P}<0.01)$.

On the 5th day of germination, the sprout length was significantly higher in the second group by $35.0(\mathrm{P}<0.05)$.

On day 5 of germination, the number of roots was approximately the same in all samples, but the length was significantly higher in experimental samples by $84.1 \%$ ( $\mathrm{P}<0.01)$ and $64.1 \%(\mathrm{P}<0.01)$, respectively.

This indicates that water from the experimental reservoir, saturated with nutrients, accelerates the growth of wheat grains.

As a result, it was found that the level of metabolic energy in all groups was $1.33 \mathrm{MJ} / \mathrm{kg}$, however, the dynamics of an increase in the mass fraction of crude protein in hydroponic feed was found. In the control group, germinated using tap water, the mass fraction of crude protein was $10.81 \pm 1.5 \%$.

In the second group, where water was used from the reservoir of LLC Albashi, this indicator amounted to $12.95 \pm$ $0.61 \%$, which reflects the dynamics of the increase by $2.14 \%$ relative to the control value and was generally the highest compared to other groups.

When using water from a well, the mass fraction of crude protein in hydroponic feed was $11.92 \pm 1.39 \%$, which exceeded the control by $1.11 \%$ relative to the control indicator.

The mass fraction of crude ash in the control was $1.38 \pm$ $0.02 \%$; in the second group, when using river water, this indicator unreliably decreased by $0.02 \%$, which may be explained by the tendency to increase the mass fraction of crude protein in this experiment group by $2.14 \%$.

\section{CONCLUSIONS}

Summing up the work with the aquaponic installation, it becomes clear that it can be optimized as follows: when using the protective net, it is possible to minimize the eating of plants by birds and their death from insolation, it is necessary to exclude white amur from the ichthyofauna. The data obtained indicate that in order to obtain hydroponic fodder it is advisable to use water from a regulated runoff of the Albashi River (experimental reservoir), where an aquaponic plant was used in a fish farm, saturated with nutrients for aquaponics.

\section{Acknowledgment}

The studies were performed in the framework of the Grant of the President of the Russian Federation for State Support of Young Russian Scientists on the topic: "A new method of selfoptimization of the use of the water surface of the inner freshwater bodies for growing plants without soil" MD1886.2019.11.

\section{References}

[1] V.G. Krymov, D.A. Yurin, S.I. Kononenko, E.A. Maxim, N.A. Yurina "Changes of Weight Indicators in Sturgeon Fish When Using Combined Feeds with Various Protein and Fat Contents in Closed Water Supply Installations", Int. J. of Pharmac. Res., vol. 10, iss. 4, pp. 316-322, Oct Dec, 2018.

[2] VA. Grigoriev, A.V. Kovalyova, M.N. Sorokina, "Experience of joint cultivation of klariyevy som (Clarias gariepinus burchell, 1822) and salad (Lactuca sativa 1.) method of aquaponics", Natural sci., vol. 4, no. 53, pp. 96-101, 2015.

[3] A.V. Kovrigin, V.P. Kamenko, R.A. Isayev "Development of elements of innovative automated aquapon technology of agricultural production", Belgorodsky agromir, vol. 3, pp. 8-10, 2015.

[4] N.V. Kuryleva, A.V. Yurina, "Hydroponics - as a method of growing green crops", Youth and sci., vol. 5, p. 69, 2016.

[5] N.N. Mamasya, O.V. Ryabtseva, E.V. Solodovnik, "Research in the Catch of Rivers of the Steppe Zone of Krasnodar Territory", Sci. J. of KubGAU, vol. 83, no. 09, 15 p., 2012

[6] I.S. Belyuchenko, "Small Rivers Kubani, state and prospects of development of their biota", Sci. J. KubGAU, vol. 106, no. 02, 22 p., 2015

[7] M.L. Gordievsky, E.I. Kolovaya, V.V. Evchenko, “Acceleration of plant growth and development by using organic irrigation solutions in hydroponic fodder production", APK of Russ., vol. 73, pp. 129-133, 2015 .

[8] S.E. Boxman, S.J. Ergas and M.A. Trotz, "Evaluation of water treatment capacity, nutrient cycling, and biomass production in a marine aquaponic system," Ecological Engineering, 2018, vol. 120, pp. 299310 .

[9] N.A. Yurina, A.G. Koshchaev, D.V. Osepchuk, E.A. Maksim, A.A. Danilova, D.V. Shumeiko, "Artificial ecological system hydroponics: the wheat grains germination rate", Int. J. of Engineer. and Advan. Technol., vol. 9, no. 1, pp. 4957-4960, 2019

[10] S. Mustafa, R. Shapawi, Aquaculture ecosystems: adaptability and sustainability, 2015, 384 p.

[11] A. Greenfeld, N. Becker, J.F. Bornman, M.J.Santos, D. Ange, "Consumer preferences for aquaponics: A comparative analysis of Australia and Israel", J. of Environmental Manag., vol. 257, 109979 , 2020. Retrieved from: https://doi.org/10.1016/j.jenvman.2019.109979.

[12] A. Cohen, S. Malone, Z. Morris, M. Weissburg, B. Bras, "Combined Fish and Lettuce Cultivation: An Aquaponics Life Cycle Assessment”, vol. 69, pp. 551-556, 2018. Retrieved from: https://doi.org/10.1016/j.procir.2017.11.029.

[13] N.E. Tregubova, "Comparison of methods of growing greens by traditional method and hydroponics at home", Young sci., vol. 33, no. 167, pp. 68-71, 2017. Retrieved from: https://moluch.ru/archive/167/45359/ (date of appeal: 01.05.2020).

[14] N.A Yurina, D.A. Yurin, E.A. Maxim, A.A. Danilova, I.R. Tletseruk, "Germination of the seeds of lettuce using the aquaponic method", Amazonia Investiga, vol. 9, no. 25, pp. 279-284, 2020.

[15] O.V. Bayanova, S.L Maksimova, Methods of research activity on ecology (for heads of associations of ecological-biological and natural science). Tyumen, 2013, $120 \mathrm{p}$.

[16] Methods of research in vegetable growing: lecture course. Saratov, 2014, $67 \mathrm{p}$. 